ВІСНИК

ОДЕСЬКОГО НАЦІОНАЛЬНОГО

МОРСЬКОГО УНІВЕРСИТЕТУ

№ 1 (64), 2021
HERALD

OF THE ODESSA NATIONAL

MARITIME UNIVERSITY № 1 (64), 2021

УДК 534.3

DOI 10.47049/2226-1893-2021-1-124-139

\title{
ДИНАМІКА ЗАХИСТУ ЖИТЛОВОЇ ЗОНИ \\ АКУСТИЧНИМИ ЕКРАНАМИ ВІД ВПЛИВУ ТРАНСПОРТНИХ ПОТОКІВ ПОРТУ «ПІВДЕННИЙ»
}

\author{
А.В. Беспалова \\ д.т.н., професор, \\ завідувач кафедри «Організація будівництва та охорона праці» \\ О.І. Книш, О.П. Дашковська, О.А. Файзуліна \\ к.т.н., доценти, доценти кафедри «Організації будівництва та охорони праці» \\ Одеська державна академія будівниџтва та архітектури
}

\begin{abstract}
Анотація У статті висвітлено норми рівня шуму житлових зон забудови, заходи щодо забезпечення нормованого рівня шуму. Наведено норми шуму транспортних засобів в залежності від відстані до житлової зони, розрахунок нормованого рівня шуму, а так само запропоновано спосіб зниження рівня шуму за допомогою шумозахисних екранів.

Запропоновані схеми акустичного розрахунку поглинання екранів 3 додаванням особливостей конструкцій екранів. 3 урахуванням часткових складових екранів наведені оптимальні комбінації щяодо вузлів конструкцій екранів, їх можливих гармонійних впливів з метою попередження взаємовібрачій аеродинамічного та структурного походження. Надано схеми компенсачійних розрахунків із використанням спеціальних програм сімейства COMSOL та спорідненого програного забезпечення акустичного контролю.

Запропоновані методи розрахунку, що виключають можливість виникнення акустичного резонансу аеродинамічного та структурного походження на етапах монтажу конструкиій шумозахисних екранів. На етапах попередження взаємовібраиій конструкиій переглянута можливість об'єднання окремих блоків з алгоритму визначення акустичного ефекту за рахунок конструктивного та ландшафтного дизайну. До блоку COMSOL додана корегуюча ландшафтно-дистаниійна складова задля попередження акустичних вібрацій з боку екранів та їх конструктивних зв'язків з опорними елементами шумозахисної системи шляхової системи магістралі.
\end{abstract}

Ключові слова: шум, норма шуму, захист від шуму, зниження звуку в житлових зонах, шумозахисні екрани.

(С Беспалова А.В., Книш О.І., Дашковська О.П., Файзуліна О.А., 2021 
УДК 534.3

DOI 10.47049/2226-1893-2021-1-124-139

\title{
ДИНАМИКА ЗАЩИТЫ ЖИЛИЩНОЙ ЗОНЫ АКУСТИЧЕСКИМИ ЭКРАНАМИ ОТ ВОЗДЕЙСТВИЯ ТРАНСПОРТНЫХ ПОТОКОВ ПОРТА «ЮЖНЫЙ»
}

\author{
А.В. Беспалова \\ д.т.Н., профессор, \\ заведующий кафедрой «Организация строительства и охраны труда» \\ О.И. Кныш, О.П. Дашковская, О.А. Файзулина \\ кандидаты технических наук, доценты, \\ доценты кафедры «Организация строительства и охраны труда»
}

Одесская государственная академия строительства и архитектуры

Аннотация. В статье освещены нормы уровня шума жильх зон застройки, меры по обеспечению нормированного уровня шума. Приведены нормы шума транспортных средств в зависимости от расстояния до жилой зоны, расчет нормированного уровня шума, а также предложен способ снижения уровня шума с помощью шумозащитных экранов.

Предложены схемы акустического расчета поглощения экранов с добавлением особенностей конструкиий экранов. С учетом частичных составляющих экранов приведены оптимальные комбиначии по узлам конструкиий экранов, их возможных гармонических воздействий с иелью предупреждения взаимовибрачий аэродинамического и структурного происхождения.

Предоставлены схемы компенсачионных расчетов с использованием специальных программ семейства COMSOL и родственного программного обеспечения акустического контроля.

Предложены методы расчета, исключающие возможность возникновения акустического резонанса аэродинамического и структурного происхождения на этапах монтажа конструкиии шумозащитных экранов. На этапах предупреждения взаимовибрачий конструкций пересмотрена возможность объединения отдельных блоков по алгоритму определения акустического эффекта за счет конструктивного и ландиафтного дизайна.

В блок COMSOL добавлена корректирующая ландшафтно-дистаниионная составляющая для предупреждения акустических вибраџий со стороны экранов и их конструктивных связей с опорными элементами шумозащитной системы дорожной системы магистрали.

Ключевые слова: шум, норма шума, защита от шума, снижение звука в зонах проживания, шумозащитные экраны. 
UDC 534.3

DOI 10.47049/2226-1893-2021-1-124-139

\title{
DYNAMICS OF PROTECTION OF THE RESIDENTIAL AREA BY ACOUSTIC BARRIERS AGAINST THE INFLUENCE OF TRANSPORT FLOWS OF THE PORT «YUZHNY»
}

\author{
A.V. Bespalova \\ Doctor of Technical Sciences, professor, \\ head of the department «Organization of construction and labor protection» \\ O.I. Knysh, O.P. Dashkovskaya, O.A. Faizulina \\ Candidates of technical sciences, associate professors of the department \\ «Organization of construction and labor protection» \\ Odessa State Academy of Civil Engineering and Architecture
}

\begin{abstract}
The article highlights the noise losses in housing development areas, measures to ensure normalized noise level. The noise standards of vehicles depending on the distance to the residence zone, the calculation of the normalized noise level, and a method for reducing the noise level with the use of noise protection screens are presented. This paper describes a semi-empiric model and measurements of air-borne sound generated by breaking sea waves and transport phone. The noise protection device is designed to suppress noise in the upper local zone and can be used at stationary workplaces. Sound pressure level measurement is carried out in octave bands with Mid-band frequencies. For the purpose of experimental measurements, the investigated area is a three-dimensional grid of a certain size, which in the software package is modeled as a cylindrical area with several nesting levels. The color solution in the cells will depend on the accepted concept of evaluating the results: a) an assessment of the degree to which the actual sound pressure level exceeds the maximum permissible value, or b) an assessment of the distribution of sound pressure levels over the entire threedimensional field of study. The choice of grid size affects the number of nodes at which sound pressure levels at a certain frequency will be measured using instrumental methods. Measurements have been performed at the Black Sea. Shores with different slopes and sediment types have been investigated. Results showed that the sound pressure level increased from $60 \mathrm{~dB}$ to $78 \mathrm{~dB}$ at 2,0 $\mathrm{m}$ noise protection screens. A scaling model based on the dissipated wave power and a surf similarity parameter is proposed and compared to measurements. The predictions show satisfactory agreement to the measurements. Acoustic-structure interaction (ASI) problems require modeling elastic waves in solids, 1pressure waves in wind fluids, and the interaction between the two. Uses of ASI include devices that generate, scatter, transmit, or receive sound and mechanical systems for sound distribution, insulation, or noise cancellation. These acoustic systems usually involve wind fluids and solid parts, and to predict their behavior, it's important to capture what happens at the wind fluid-solid interfacing boundaries.
\end{abstract}

Keywords: noise, noise level, reducing the noise level, noise protection screens safety to the residence zone. 
Постановка проблеми. Планування і забудова земель міських і сільських поселень здійснюється з урахуванням забезпечення допустимих рівнів шуму в приміщеннях житлових і громадських будівель і на їх території. Особливу роль відіграють зовнішні умови розміщення ділянок, особливо тих що відрізняються ландшафтним характером «заводьберегова лінія» та «селітебна забудова - гідротехнічна споруда» і т. інш. Регулювання засобів та заходів захисту території значно ускладнюється зростаючими обсягами штучно-техногенної природи. Існуюча нормативно-технічна база технічно недосконала та заслуговує інженерного аналізу із подальшим переглядом. Постійно змінюються та оновлюються системи захисту території, наприклад, від постійно діючого транспортнотехнологічного навантаження. Ступнево зростає технологічне оснащення захисту. Брак вільної площі вимагає від розробників детального аналізу та проектних рішень щодо конструктивного оформлення споруд захисту.

Огляд останніх досліджень та літератури. Захист від транспортного шуму повинен здійснюватися шляхом: застосування раціональних планувальних прийомів, що передбачають зонування територій міських і сільських поселень; раціональне трасування вулично-дорожньої мережі; розміщення спеціальних шумозахисних будівель уздовж транспортних магістралей; застосування різних композиційних прийомів угруповання шумозахисних і звичайних будівель; організаційних заходів, спрямованих на обмеження руху вантажного транспорту і на зниження швидкості руху транспортних засобів при проїзді через житлові, рекреаційні та лікувальні території; конструктивні заходи, що передбачають будівництво придорожніх екранів, облаштування шумозахисних вікон в будівлях, розташованих в зоні несприятливого шумового впливу. На етапі розробки схеми під'їзних шляхів м. Південне Одеської області з метою зниження впливу шуму на територію слід застосовувати такі заходи: функціональне зонування території селища 3 відділенням рекреаційних зон від промислових, комунально-складських зон і основних транспортних комунікацій; трасування магістральних доріг швидкісного i вантажного руху [1]. При виконанні проекту планування житлового району м. Південне для захисту від шуму приймалися наступні заходи: використання шумозахисних екранів у вигляді природних або штучних елементів рельєфу місцевості $[1 ; 2]$; в якості будівель-екранів використовувалися будівлі нежитлового призначення: гаражі, підприємства комунально-побутового обслуговування. Найбільш ефективні багатоповерхові шумозахисні житлові та адміністративні будівлі. В умовах м. Південне в більшості випадків найбільш доцільно спорудження шумозахисних акустичних екранів у вигляді вертикальних або похилих стінок різної конструкції, які $є$ найбільш технологічними для практичного застосування. Природні шумозахисні екрани-споруди у вигляді стінки, земляного насипу, галереї, встановлені вздовж автомобільних доріг з метою зниження шуму [3]. Акустичні екрани повинні спиратися на самостійні 
фундаменти. Всі їх конструктивні елементи повинні бути механічно міцними і розрахованими на вплив снігових, вітрових і сейсмічних навантажень. Ефективність акустичного екрану може бути збільшена (до 3 дБА) при обробці поверхні екрану, зверненої до джерела шуму, матеріалами з високим звукопоглинанням або установкою на верхньому ребрі екрану спеціальних конструктивних елементів для збільшення розсіювання і поглинання дифрагуючої звукової хвилі. Враховуючи, що частина звукової енергії може проникати за екран безпосередньо через сам екран, слід підбирати індекс ізоляції повітряного шуму конструкції екрану не менше 25 дБА [2; 3]. Висоту акустичних екранів найбільш доцільно вибирати в межах 3-6 м в залежності від висоти будівель, що захищаються від шуму i ïx розташування щодо магістралі. Довжина екранів може становити сотні метрів і навіть кілька кілометрів [3]. У процесі вивчення функціональних зон м. Південне встановлений той факт, що між лінією автодорожнього шляху і житловою зоною при відстані в 100 м немає ніякого захисту від шумової дії транспорту (рисунок 1).

У розпорядженні проектувальників транспортної інфраструктури $\epsilon$ досить обмежений набір засобів захисту від шуму: звукоізолююче скління, звукопоглинаючий асфальт (не більше 3 дБА), екрануючі земляні споруди (до 10-12 дБА), шумозахисні екрани (до 15 дБА).

Для стаціонарних установок і систем використовують глушники шуму (до 12 дБА) і звукоізолюючі капоти (до 10 дБА), звукоізолююче скління і шумозахисні екрани. Найбільш ефективним засобом захисту від шуму є шумозахисні екрани 2-х типів: транспортні, що встановлюються поблизу автомобільних, i технологічні, що встановлюються поблизу стаціонарних джерел шуму (чилери, дизель-електростанції і т.і.). На підставі вивчення технічних, акустичних і технологічних властивостей $\mathrm{i}$ особливостей сучасних шумозахисних екранів і визначено наступне завдання дослідження: розробити або уточнити методики визначення акустичних властивостей шумозахисних екранів в натурних умовах, розробити стенди і методики дослідження сучасних транспортних і технологічних шумозахисних екранів. Наведено результати комплексного натурного обстеження 50 шумозахисних екранів 3 оцинкованої сталі, імпрегнованої деревини, алюмінію, полікарбонату та ін. $з$ різними термінами служби від 1 року до 5 років. Виконані вимірювання в житловій забудові на відстані 100 м від різних джерел шуму підтвердили перевищення еквівалентних рівнів звуку: автомобільні дороги на 8-20 дБА, промислові підприємства на 5-18 дБА.

Фактична ефективність шумозахисних екранів становить на автомобільних дорогах 5-12 дБА та відрізняється від розрахункової (в проектній документації) в два і більше разів (рисунок 2), що пов'язано 3 помилками, як при проектуванні, так і на стадії монтажу екранів. 
ВІСНИК

ОДЕСЬКОГО НАЦІОНАЛЬНОГО

МОРСЬКОГО УНІВЕРСИТЕТУ
HERALD

OF THE ODESSA NATIONAL

MARITIME UNIVERSITY № 1 (64), 2021
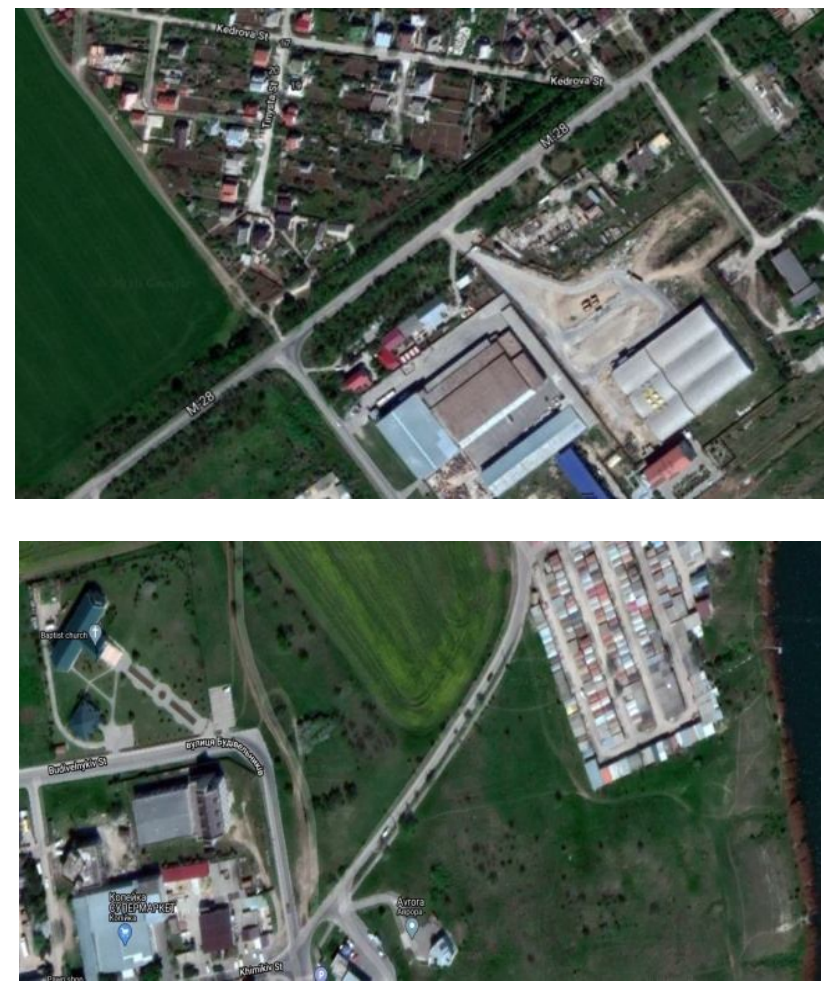

Рис. 1. Автотраса і житлова забудова

Згідно з проведеним аналізом, у 85 \% випадків була обрана неправильна довжина, а у $38 \%$ випадків - невірна висота екранів. Найбільш частими помилками проектування і монтажу також є: невідповідність кроку стійок і фундаменту.

$\triangle \mathrm{L}, \mathrm{B} \mathrm{BA}$

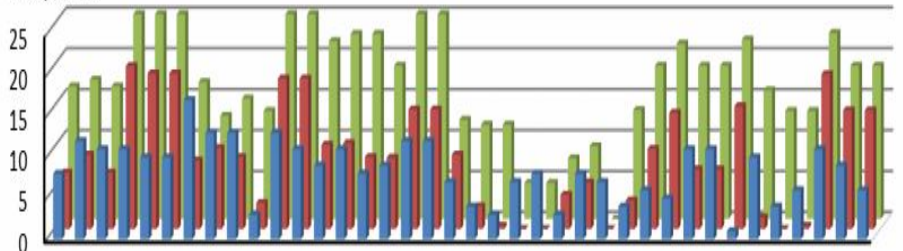

ص Фактична ефективність

Розрахункова ефективність для дал.смуги

무 Розахункова ефективність для ближн.смуги

Рис. 2. Порівняння розрахункової та фактичної ефективності ШЕ

Основний матеріал дослідження. Емпірично визначені акустичні властивості експлуатованих ШЕ: звукоізоляція (3І) і звукопоглинання (коефіцієнт звукопоглинання). Отримані експериментальні значення 
звукоізоляції складають в середньому від 15-18 дБА (68 \% вимірювань) до 20-22 дБА (12\%). Заявлена вітчизняними виробниками звукоізоляція 31-36 дБА є завищеною майже в 2 рази. Експериментами в натурних умовах встановлено також невисоку якість звукопоглинання: середнє значення коефіцієнта звукопоглинання 0,45-0,6 при гарантії виробника 0,9-1,0 (рис. 3,4 ). Ця невідповідність пояснюється застосуванням звукопоглинального матеріалу низької якості і неправильною експлуатацією ШЕ.

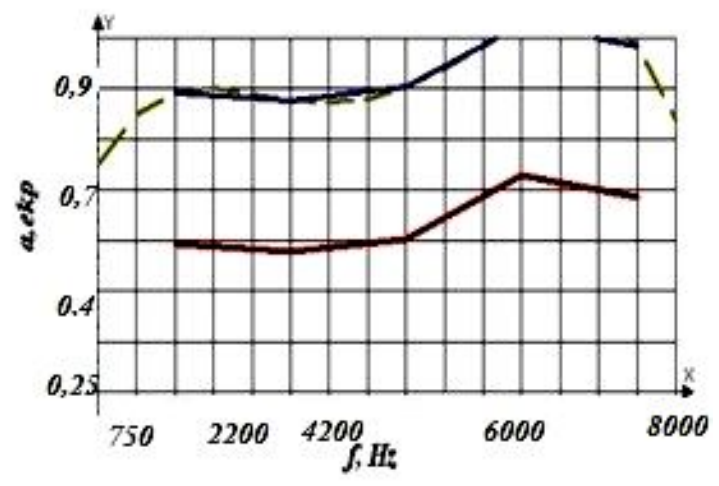

Рис. 3. Усереднені характеристики шумозахисних екранів

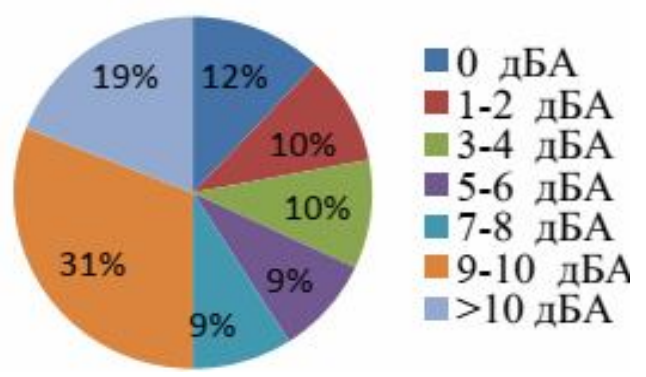

Рис. 4. Перевищення еквівалентних рівнів звуку

на селітебній території характеристики шумозахисних екранів

Останнім етапом виконаного обстеження була перевірка на відповідність ШЕ заявленим проектними даними вимогам. Було встановлено, що до 80 \% змонтованих ШЕ не забезпечують зниження шуму до норми, при цьому перевищення на селітебній території еквівалентних рівнів звуку становлять від 1 до 14 дБА. Причинами такого становища $\epsilon$ необгрунтовані технічні рішення, застарілі технології, що використовуються на практиці. 
На підставі уточненої теорії і наведені результати досліджень акустичної ефективності шумозахисних екранів. В основу розробленої теорії покладено уявлення про звукові поля, де основною ідеєю було замінити поля одиничних відбить звуку [4] на багаторазові перевідбиття у присутності поверхонь джерел шуму, ШЕ, опорної та інших відбиваючих поверхонь (рис. 5). Звукове поле тут створюється в умовному просторі, що створено згаданими поверхнями.

a)

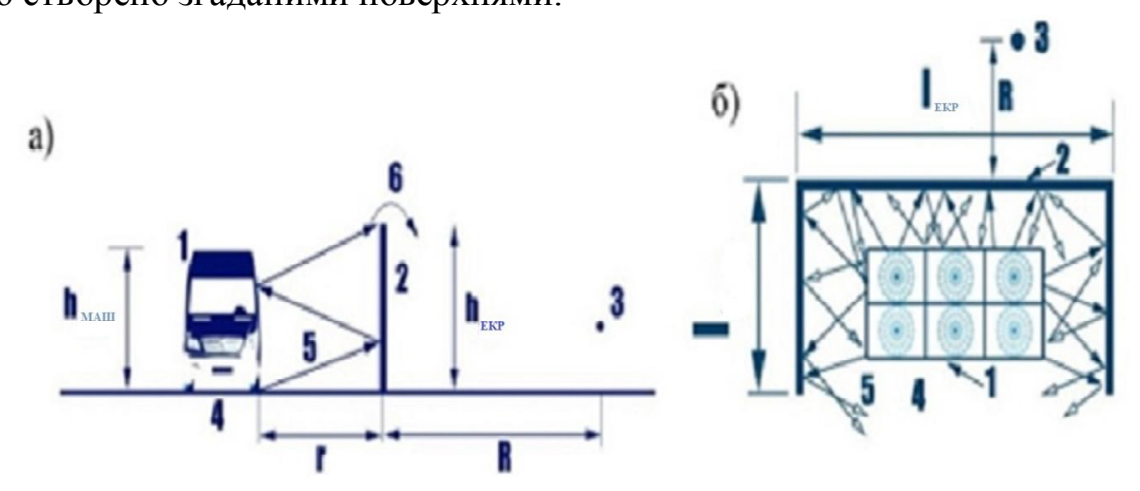

Рис. 5. Характер звукового поля перед транспортним (а)

i технологічним (б) шумозахисними екранами:

1 - ДШ; 2- шумозахисний екран; 3 - РT; 4 - опорна поверхня; 5 - багаторазові відбиття звуку;

6 - дифракція звуку на вільному ребрі шумозахисного екрану

Основними положеннями і припущеннями уточненої теорії шумозахисних екранів $€$ наступні: звукове поле, створюване в умовному обсязі, утвореному джерелами шуму, шумозахисним екраном і опорною поверхнею; для урахування явищ дифракції на вільному ребрі шумозахисного

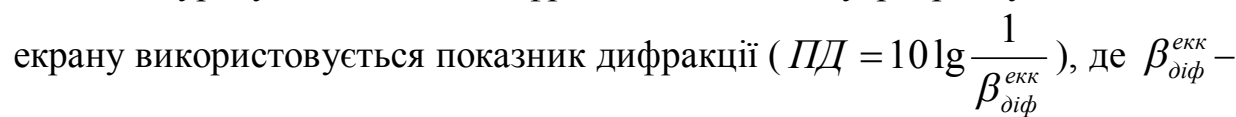
коефіцієнт дифракції екрану, що показує відношення інтенсивності дифрагованого звуку до інтенсивності падаючого звуку на вільне ребро екрану); за рекомендацією [5] застосовано поняття ефективної висоти шумозахисного екрану - перпендикуляр 3 вершини вільного ребра на умовну лінію, що з'єднує джерела шуму і розрахункову точку (рис. 6); шумозахисний екран розглядається як звуконепроникна конструкція; джерела шуму для транспортних шумозахисних екранів розглядаються у вигляді лінійних випромінювачів циліндричних звукових хвиль. 
a)
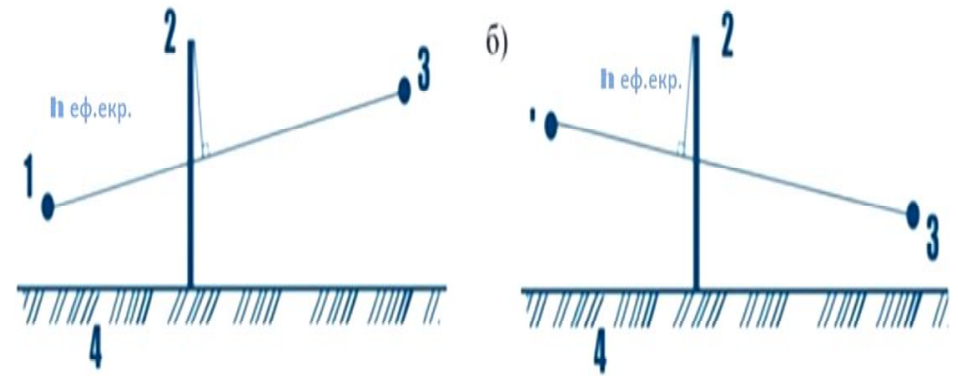

Pис. 6. Ефективна висота шумозахисного екрану:

1 - ДШ; 2 -ШЕ; 3 - РТ; 4 -опорна поверхня

Нижче наведені розрахункові схеми та отримані варіативні моделі на базі залежності Релея із використанням виправлень Гюйгенса, що розповсюджені на методи променевих траєкторій в умовах багаторазового відбиття прямих огинаючих хвиль (таблиця). Геометричні розміри екранів наводяться із поправками на кути відбиття прямих звукових хвиль. Особлива увага приділяється взаєморозташуванню екрануючих поверхонь, що враховано хвильовим числом у вигляді додатка до коефіцієнта зниження інтенсивності акустичного поля.

На підставі теоретичних досліджень щодо встановлення зв'язку акустичної ефективності ШЕ з їх конструктивними параметрами і акустичними властивостями. На рис. 7 показана залежність ефективності ШЕ від геометричних властивостей умовного простору, а на рис. 8 - від його акустичних властивостей.

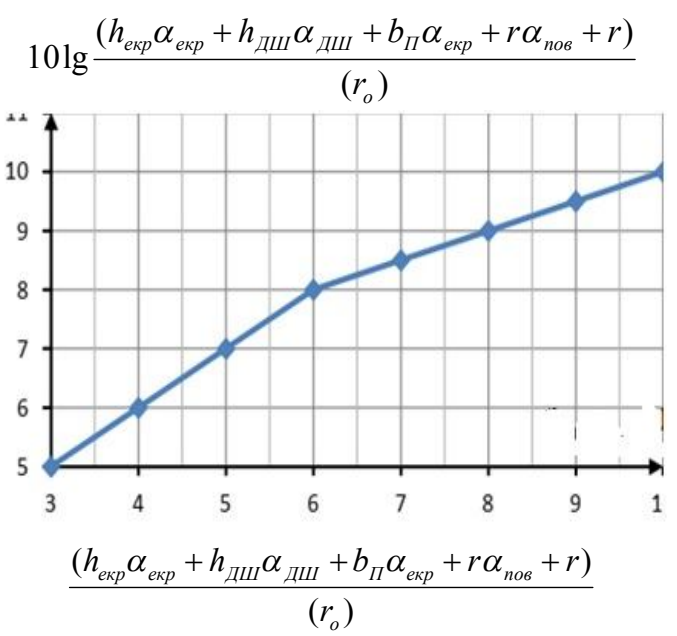

Рис. 7. Вплив геометричних властивостей умовного об'єму 


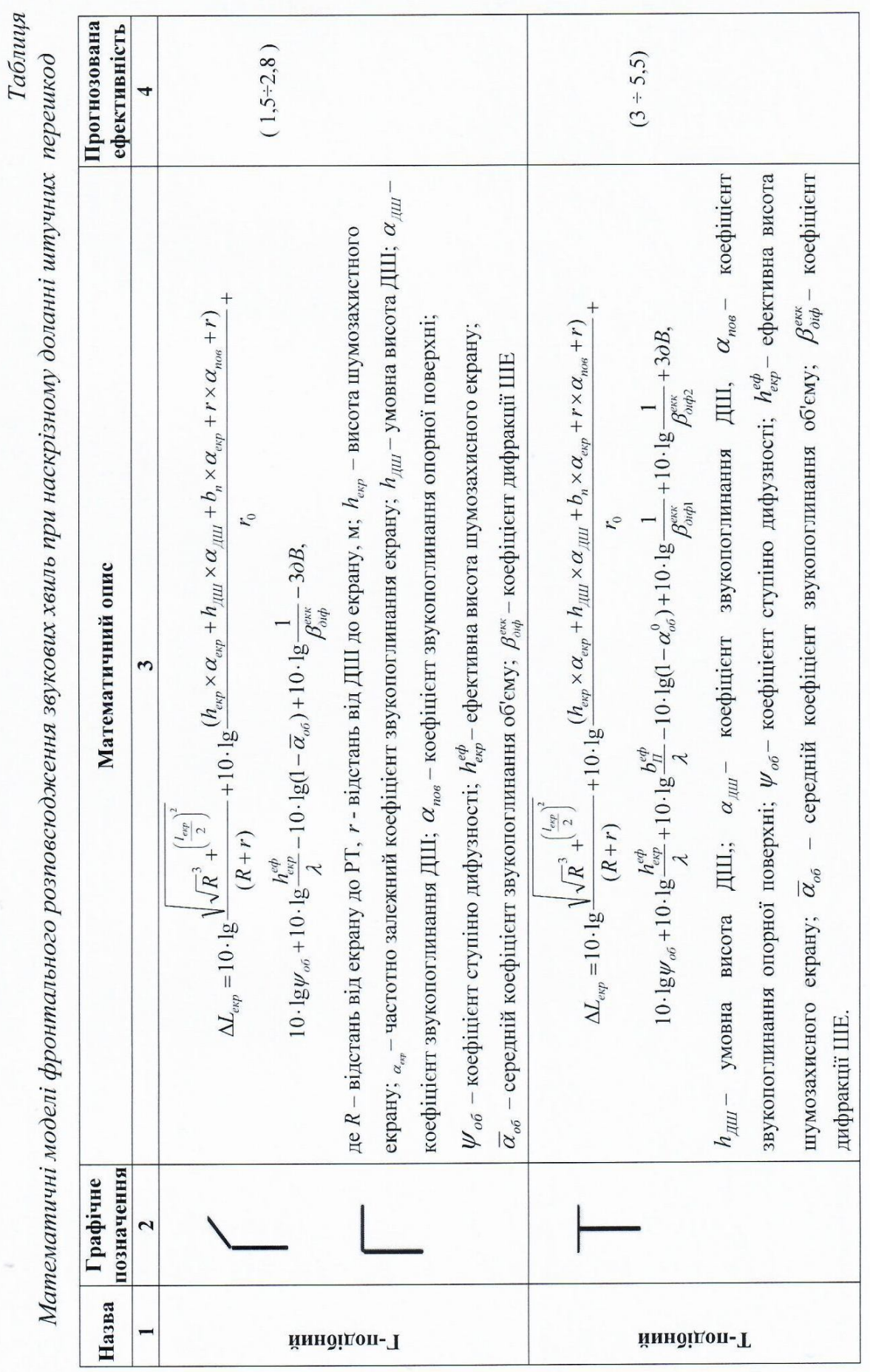


ВІСНИК

ОДЕСЬКОГО НАЦІОНАЛЬНОГО

МОРСЬКОГО УНІВЕРСИТЕТУ

№ 1 (64), 2021
HERALD

OF THE ODESSA NATIONAL MARITIME UNIVERSITY № 1 (64), 2021

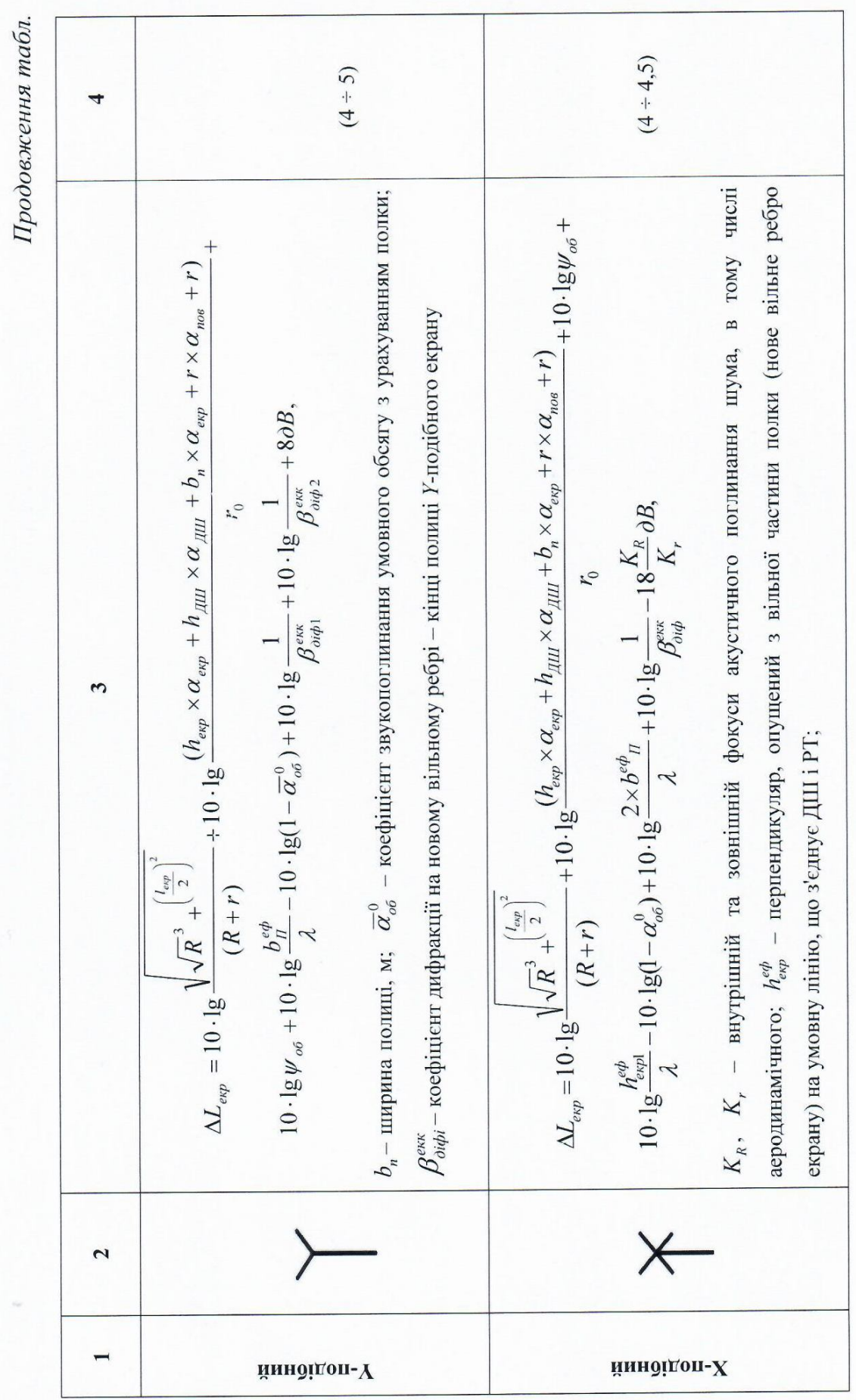


ВІСНИК

ОДЕСЬКОГО НАЦІОНАЛЬНОГО

МОРСЬКОГО УНІВЕРСИТЕТУ

№ 1 (64), 2021
HERALD

OF THE ODESSA NATIONAL

MARITIME UNIVERSITY № 1 (64), 2021

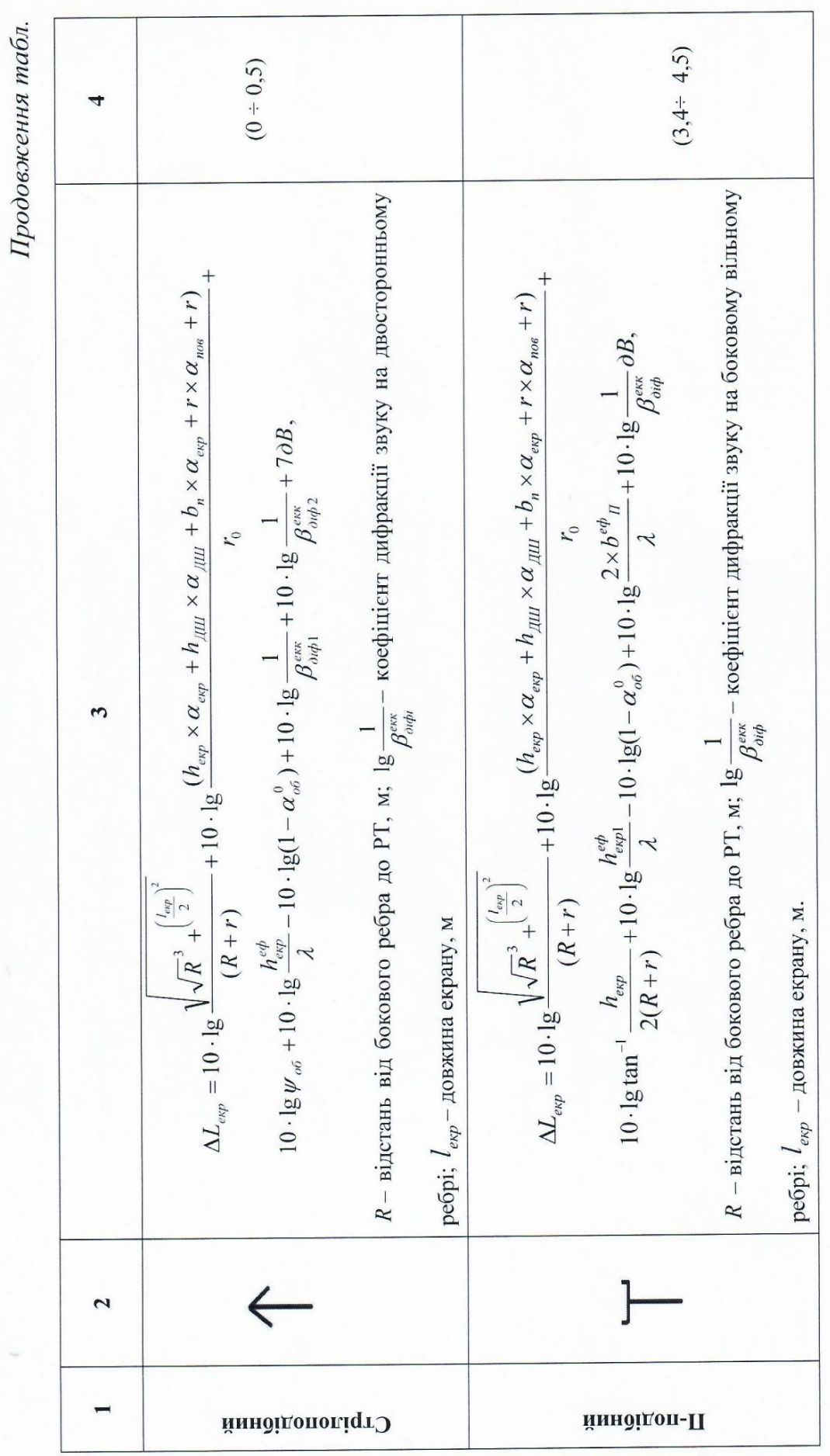


У межах практично реалізованих параметрів вплив першого показника від 5 до 10 дБ, другого від 1 до 4 дБ. Г-подібна надбудова забезпечує додаткову ефективність в 1-2 дБ, Т-подібна - від 2 до 8 дБ.

$10 \lg \times\left[\left(1-\bar{\alpha}_{o \bar{\sigma}}^{o}\right)\right]$

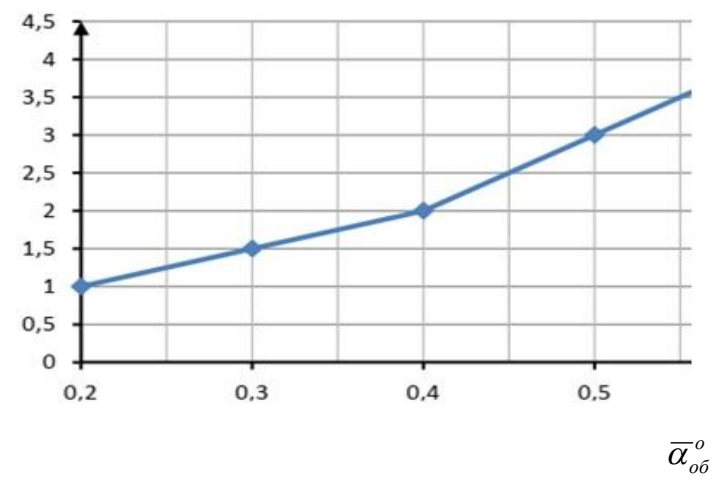

Рис. 8. Вплив акустичних властивостей умовного об'єму

Аналіз отриманих даних дозволяє оцінити роль естакади і їі розташування по відношенню до розрахункової точки в збільшенні акустичної ефективності ШЕ. Ефективність екрану зростає при збільшенні різниці кутів в межах обраних значень від 3,5 дБА $\left(10^{\circ}\right)$ до 6 дБА $\left(60^{\circ}\right)$.

Найбільші зміни отримані в діапазоні різниці кутів $10-40^{\circ}$ (зростання від 3,5 дБА до 5 дБА), а при подальшому збільшенні кута це зростання не перевищує 1 дБА (рис. 9) [6].

Також вивчається вплив ширини щілини на акустичну ефективність ШЕ (рис. 10).

$\Delta L_{\text {cep. }}^{щ}, d B$

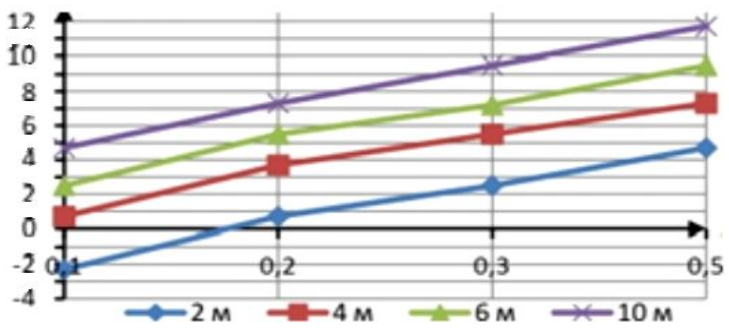

$$
b^{\amalg}, M
$$

Рис. 9. Обчислена залежність висоти екрана на частоті 1000 Ги при різних значеннях висоти естакад 


$$
10 \times \lg \frac{h_{\text {екp }} \pm h_{\text {eкp }} \times \sin \left(\varphi_{1}-\varphi_{2}\right)}{\lambda}, d B
$$

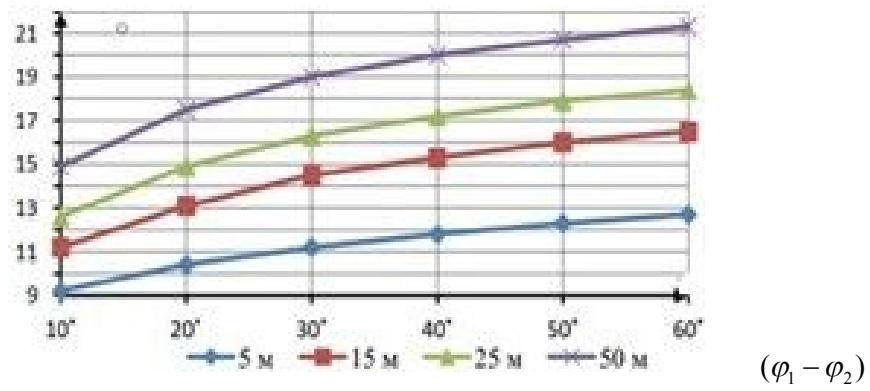

Рис. 10. Залежність акустичної ефективності від кута падіння на частоті 1000 Ги

Висновки. Аналіз показує, що збільшення ширини щілини від 0,1 до 0,5 м знижує акустичну ефективність шумозахисного екрану на 5-6 дБ. Зниження ефективності екранів за інтегральним значенням може досягати від 5 до 12 дБА.

Індекс ізоляції повітряного шуму становить 37 дБА [7]. Досягнуті звукопоглинаючі і звукоізолюючі властивості панелей екрану забезпечать високу ефективність їх застосування в якості захисту від шуму транспортних засобів [7]. Властивості шумопоглинаючого екрану: висока здатність до шумопоглинання; пожежо-, вибухобезпечність; стійкість до агресивного середовища; легкий монтаж і демонтаж при ремонті; легкомиюча поверхня.

За результатами досліджень можна помітити, що при плануванні і забудові м. Південне не були дотримані вимоги щодо захисту житлової зони поселення від шуму автотраси на 100 м, але вдається зменшити шумовий вплив до нормативних показників. Ще необхідна установка уздовж паркувальних місць шумозахисних екранів.

\section{ЛIТЕРАТУРА}

1. Про затвердження Програми розвитку інфраструктури м. Южного на 2020-2022 роки: база даних Южненська міська рада Одеської області України. URL: http// http:// yuzhny. gov.ua/ rish/ 50030 (дата звернення: 28.02.2020).

2. Zienkiewicz O.C. Finite Element Method / O.C. Zienkiewicz, R.L. Taylor. - UK: Butterworth-Heinemann, 2000, Vol. 1. ISBN: 978-0750650496.

3. Автомобільні дороги. Споруди шумозахисні. Вимоги до проектування: ГБН В.2.3-37641918-556:2015. - К.: Міністерство інфраструктури Украӥни, 2015. - 30 с. 
4. Методи й засоби захисту інформації / В.А. Хорошко, А.А. Чекатков. - К.: Юніор, 2003. - 504 c.

5. Акустический проект помещения: Методические указания к курсовой работе по дисииплине «Акустика» / Е.С. Белоус, Б.М. Бескоровайный, В.Б. Галаненко, В.Т. Гринченко, М.И. Карновский, Б.И. Шочкий. - К.: КПИ, 1985. - 68 с.

6. Федотов Е.С., Кустов О.Ю., Храмчов И.В., Пальчиковский В.В. Сравнительный анализ акустических интерферометров на основе расчётно-экспериментальных исследований образиов звукопоглощчающих конструкций // Вестник Пермского национального исследовательского политехнического университета: Аэрокосмическая техника. - 2017. - № 48. C. 89-103.

7. Храмиов И.В., Кустов О.Ю., Федотов Е.С., Пальчиковский В.В., Синер А.А. Численное моделирование акустических прочессов в интерферометре с образиами многослойных звукопоглощаюших конструкций // Вестник Пермского национального исследовательского политехнического университета: Аэрокосмическая техника. 2017. - № 51. С. 5-15.

\section{REFERENCES}

1. Pro zatverdzhennja Programi rozvitku infrastrukturi m. Juzhnogo na 2020-2022 roki: baza danih Juzhnens'ka mis'ka rada Odes'koï oblasti Ukraïni. URL:http// http://yuzhny.gov.ua/rish/50030 (data zvernennja: 28.02.2020).

2. Zienkiewicz, O.C. Finite Element Method / O.C. Zienkiewicz, R.L. Taylor. - UK: Butterworth-Heinemann, 2000, Vol. 1. ISBN: 978-0750650496.

3. Avtomobil'ni dorogi. Sporudi shumozahisni. Vimogi do proektuvannja: GBN V.2.3-37641918-556:2015. - K.: Ministerstvo infrastrukturi Ukraïni, 2015. - 30 s.

4. Metodi j zasobi zahistu informaciï / V.A. Horoshko, A.A. Chekatkov. - K.: Junior, 2003. - 504 s.

5. Akusticheskij proekt pomeshhenija: Metodicheskie ukazanija $k$ kursovoj rabote po discipline "Akustika» / E.S. Belous, B.M. Beskorovajnyj, V.B. Galanenko, V.T. Grinchenko, M.I. Karnovskij, B.I. Shockij. - K.: KPI, 1985. - 68 c.

6. Fedotov, E.S., Kustov, O.Ju., Hramcov, I.V., Pal'chikovskij, V.V. Sravnitel'nyj analiz akusticheskih interferometrov na osnove raschjotno-jeksperimental'nyh issledovanij obrazcov zvukopogloshhajushhih konstrukcij // Vestnik Permskogo nacional'nogo isledovatel'skogo politehnicheskogo universiteta. Ajerokosmicheskaja tehnika. - 2017. - № 48. - S. 89-103. 
ВІСНИК

ОДЕСЬКОГО НАЦІОНАЛЬНОГО

МОРСЬКОГО УНІВЕРСИТЕТУ

№ 1 (64), 2021
HERALD

OF THE ODESSA NATIONAL

MARITIME UNIVERSITY № 1 (64), 2021

7. Hramcov, I.V., Kustov, O.Ju., Fedotov, E.S., Pal'chikovskij, V.V., Siner, A.A. Chislennoe modelirovanie akusticheskih processov $v$ interferometre s obrazcami mnogoslojnyh zvukopogloshhajushhih konstrukcij // Vestnik Permskogo nacional'nogo issledovatel'skogo politehnicheskogo universiteta // Ajerokosmicheskaja tehnika. 2017. - № 51. S. 5-15.

Стаття надійшла до редакиії 11.03.2021

Посилання на статтю: Беспалова А.В., Книш О.І., Дашковська О.П., Файзуліна О.А. Динаміка захисту житлової зони акустичними екранами від впливу транспортного шуму // Вісник Одеського національного морського університету: Зб. наук. праць, 2021. № 1(64). C. 124-139. DOI 10.47049/22261893-2021-1-124-139.

Article received 11.03.2021

Reference a JournalArtic: Bespalova A.V., Knysh O.I., Dashkovskaya O.P., Faizulina O.A. Dynamics of protecting the housing area with acoustic screens against transport noise // Herald of the Odessa National Maritime University. 2021. 1(64), 124-139. DOI 10.47049/2226-1893-2021-1-124-139. 